\title{
Embalming - History to its Recent Advancements
}

${ }^{\star}$ Sunil Shrestha ${ }^{1}$, Saru Bhattarai ${ }^{1}$, Samyog Mahat ${ }^{2}$, Manisha Jha ${ }^{2}$, Kapil Amgain ${ }^{3}$

\section{Authors Info:}

${ }^{1}$ Postgraduate student, Department of Human Anatomy, B.P. Koirala Institute of Health Sciences (BPKIHS), Dharan, Nepal ${ }^{2}$ Senior Resident, Department of Human Anatomy, BPKIHS, Dharan, Nepal ${ }^{3}$ Assistant Professor, Dept. of Clinical Anatomy of Cell Biology, Karnali Academy of Health Sciences, Jumla, Nepal

*Corresponding Author:

Sunil Shrestha

sunilmanshrestha@gmail.com

Disclaimer:

Conflict of Interest: None

Source of Support: None

Copyright (c) 2019 by author(s), licensed under the Creative Commons Attribution International License 4.0.

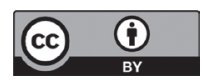

\section{ABSTRACT:}

Embalming as art and science of preserving dead bodies with postponing decomposition using embalming fluid. The method of preservation of cadavers is natural and non-natural. This study involves an extensive search of journal articles to access the trend of development of embalming technique that was developed after many trials and errors. In this paper, we have briefly discussed about the past, present and upcoming future technique of cadaver preservation with recent advances and modification. We would also like to recommend that new internationally recognized standard on embalming technique should be developed so that cadavers were excellently preserved and color remains natural.

Keywords: Embalming, Embalming Fluid, Cadaver preservation, Plastination, Recent Advances in Embalming, Formalin

\section{Article Info}

Received: October 19, 2019

Accepted: December 12, 2019

Published Online: December 15, 2019

How to cite this article in Vancouver Style?

Shrestha S, Bhattarai S, Mahat S, Jha M, Amgain K. Embalming - History to its recent advancements. Europasian J Med Sci 2019; 1(1):62-68.

https://doi.org/10.46405/ejms.v1i1.15

Access this article online

\section{Publisher Note:}

The Europasian Journal of Medical Sciences (EJMS) is an official Journal of Nirvana Psychosocial Care Center \& Ressearch Institute www.nirvanapscc.com. The Journal as well as publisher remain neutral with regards to any jurisdictional claims in any published articles, its contents and the institutional affiliations of the authors.
Quick Response (QR) Code

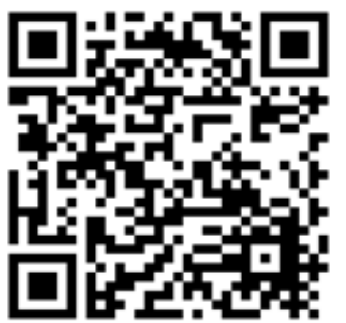

Scan Me for Full Text 


\section{INTRODUCTION}

Tuman cadaver, preservation and dissection is 1 essential from past to present and for future studies too for three dimensional structures of human body. ${ }^{1}$ It involves the embalming fluid responsible for fixing, which prevents autolysis, putrefaction, decomposition and make cadaver suitable for transportation, preservation, funeral, or study purpose. Therefore, the goals of embalming are preservation, sanitation and preservation. Human embalming has ancient and long cross-cultural history showing religious importance, which supposed to start from ancient Egyptians for preservation of their mummies before $4000 \mathrm{BC}$ and used for 30 centuries. After 1832 and 1871 AD, when anatomy acts passed into law comes into lime light which permitted to embalmed the dead bodies for medicolegal purpose, anatomical researches and long distance transport for the funeral. ${ }^{2}$ In modern history, the first man who started embalming by chemical preservative solution with unknown technique was believed to be to be Dutch anatomist Fredrik Ruysch. Later after discovery of preservative formaldehyde in 1867 which laid a strong stone foundation for modern method of embalming and used in corpse during the American civil war. ${ }^{3}$

\section{DISCUSSION}

\section{History}

Embalming, the art of mixture of ancient and modern science used for preserving human remains showed long old cross-cultural history and religious beliefs. It was credited that in Egypt from 6000 BC bodies were mummified and considered to be a founder of embalming, but other ancient Ethiopian tribes, Aborginal inhabitants of Canary Island, Babylonians, Persians, Syrians, Greeks, Tibetans etc. preserved the dead bodies by mummification and placing it in jars of honey and wax. ${ }^{4}$

The procedure used by Egyptian for mummification are; ${ }^{5}$

1. Brain \& internal organs are removed and placed in a Canopic Jar.

2. In ancient period, Heart was considered as thing that controlled all thoughts, memories and intelligence by Egyptians, so it was left inside the body.
3. Then, for 40 days the body was covered by salty substance called Natron to dry out.

4. The body was filled with saw dust for life less appearance, then body was bathed with wine and spices, wrapped in the linen cloth and left for additional one month.

5. Lastly, mummified bodies placed in a mummy case and placed in coffin and then asarcophagus.

Scientific discovery in the modern medicines from time to time after the 14th century also laid important foundation in the embalming procedure. Discovery of circulation of blood by Dr William Harvey (1578-1657) leads a first successful arterial system embalming by Dr Frederick Ruysch (1665-1717) and considered to be father of embalming, later Dr William Hunter (1718-1783) who first performed the arterial injection technique for preservation also marked as an important discovery in the field of embalming. After the discovery of formaldehyde in 1867 leads the new journey of modern embalming by $\mathrm{Dr}$ Thomas Holmes (1817-1900) who experimented embalming with preservative chemicals and considered as father of modern embalming. ${ }^{2,4}$

\section{Modern Methods of Human Embalming:}

The modern method of human embalming involves the arterial, cavity, hypodermic and surface embalming process which are is not a result of single practitioners but researched, trial, error, and invention from decades and centuries. Therefore, the standard version was followed with common variation on technique was found. ${ }^{2,3,5}$

The standard principle for modern embalming 4 usually involves the following steps:

1. Exposure of large artery and vein to insert the tube inside those vessels.

2. Washing out of any blood clots or fluid that are present in the vessels for a safety purpose.

3. Running the embalming fluid which have the capacity of preservation, fixation, disinfection and also provides natural color to body via mechanical pump.

4. Massage of the corpse are done to ensure 
proper distribution of embalming fluid and tying the injection site and suturing.

The modern method involves:

\section{Conventional method}

2. Refrigeration

3. Plastination

4. Thiel's method

5. Cryopreservation

6. Saturated salt solution

Conventional Methods

The conventional method practiced in funeral homes uses several steps, most commonly used modern technique is Arterial embalming which involves the injection of the preservative embalming chemical into the blood vessels via the right common carotid artery or via femoral artery opening through femoral triangle or via right jugular vein. The cavity embalming technique involves the internal fluid of the corpse being suctioned out and later filled with concentrated formalin. The other technique used is Hypodermic embalming where chemicals are injected under skin and Surface embalming done specially for a visible injured part. The modern embalming technique fluid generally used mixture of chemicals with different concentration which forms arterial solution.

The aims of embalming chemical for anatomical purpose are complete preservation, preventing over hardening with complete softness of tissue is found in fresh un-embalmed specimen with color of muscle, organ securing brown dark color and should prevent desiccation, fungal and bacterial growth. The general potential chemical ingredients required for an arterial solution includes: ${ }^{3-6}$

- Preservatives:

Formaldehyde (18-35\%) for funeral, glutaraldehyde, Phenol, Formalin (40\% formaldehyde) for the preservation of the anatomical specimens.

- Germicides:

Thymol, Quaternary ammonium compound, glutaraldehyde

- $\quad$ Modifying Agents:
Buffers, humectants, inorganic salt which influence and controls the action of preservative agents.

- Buffers:

Borax, sodium phosphate, citrates, sodium salt of EDTA (ethylenediamine tetra acetic acid)

- Inorganic salts:

It is responsible for determining the osmotic quality of embalming solution

- Humectants:

It is used to hydrate tissue e.g. glycerol, sorbitol, glycol, lanolin

- Anticoagulants:

It reduces the viscosity of blood e.g. sodium citrate, sodium oxalate, sodium salt of EDTA

- Surfactant:

It is generally added to reduce the molecular cohesion of liquid as it can flow through small arteries and vein properly e.g. sulfonates

- Dyes:

Eosin, Ponceous red, Erythosine \& amaranth

- Perfuming agents:

Benzaldehyde, oil of cloves, methyl salicylate.

- Vehicles (diluents):

liquid that serves as solvent for the mixture of ingredients e.g. water, alcohol, glycerol.

Now, combination of these chemical on various ratio and concentration produces arterial fluid, cavity fluid, supplementary fluid, jaundice fluid, high preservation demand fluid and accessory fluid.

\section{Refrigeration}

Very cold atmosphere is also a natural form of the preservation of dead bodies which was practiced in the high land of Peru and Incas in South America. ${ }^{2}$

\section{Plastination}

The plastination is a long-term purpose preservation technique discovered by German anatomist Gunther Von Hagen's in 1977, which acts on the principle that biological fluids are replaced via plastic polymers which are devoid of the harmful effects of embalming fluids. The technique showed preservation of biological 
tissue with complete visible surface, high durability and keeps anatomical specimen dry and odourless. ${ }^{2,7}$ In medicolegal cases, the accuracy of identification, preservation of important material can be done early where injury pattern may be changed due to shrinkage but can be recognized easily. ${ }^{5}$

\section{The 3 methods involved for plastination ${ }^{2}$ are}

1. Silicone plastination (S10) method which creates opaque and natural looking specimen

2. Sheet plastination with epoxy method (E12) generally used for thin, transparent and for organ and body slices.

3. Sheet plastination with polyester method (P35) used for semitransparent and brain slices.

According to Heidelberg plastination folder8, the S10 technique involves 4 steps

1. Specimen preparation (fixation)

2. Dehydration and defatting

3. Force impregnation (via vacuum)

4. Curing (Hardening)

The process for fixation procedure starts with immersing the specimen in $10 \%$ concentrated formalin for 30 days, which was followed by the step of dehydration and defatting. The formalin fixed specimen was placed in a series of three dehydration bath of acetone through freeze substitution method at $-26^{\circ} \mathrm{C}$ followed by decreasing at room temperature for one week except Encephalon's and spinal cord. The important step of plastination is force impregnation where specimens soaked in acetone were placed in a polymer solution at $-22^{\circ} \mathrm{C}$ under vacuum pump action. The polymer mixture was achieved by mixing S10 polymers and S3 hardener at 100:1 ratio depending on the specimen texture, it may take 3 to 4 weeks for decreasing pressure from 285 mbar to 3-5 mbar, lastly curing was performed for 5 to 10 minutes daily by S6 gas using an aquarium pump. A research conducted by Pandit $S$ et al in 2015 in India explained that orthocryl and epoxy resin retained maximum color with minimum shrinkage and brain specimen was best preserved in othrocryl, while maximum coloration was present in polypropylene plastinated models. ${ }^{7}$

The modification of plastination technique was performed by Elnady FA in 2016, Egypt for tissue preservation, which is modified form of plastination where chemical used are not patent, inexpensive, locally available and performed at room temperature.

The five steps of Elnady technique ${ }^{9}$ are:

1. Fixation with formalin

2. Dye injection, muscle dissection and bone drilling

3. Dehydration with acetone

4. Impregnation in glycerin

5. Curing with corn starch

The result showed realistic, durable with no offensive odor with soft, flexible and dry showing great potential to replace costly method which can be a new innovative method for tissue preservation in animals.

\section{Cryopreservation}

Cryopreservation is a technique used to preserve the tissue cell and its organelles or any other biological specimen by cooling the sample to very low temperature of $-196{ }^{\circ} \mathrm{C} .5$ After the discovery of glycerol in $1949 \mathrm{AD}$, the scientific community had great interest in the cryopreservation of human cells. At such low temperature, all biological intracellular and extracellular activity, chemical reaction that leads to cell death ceases effectively and biological tissues are maintained in living state. ${ }^{10,11}$ Depending upon the specimen and cell type, cryopreservation process involves Slow freezing, vitrification, Subzero nonfreezing storage and preservation in dry state.

The steps are described below: ${ }^{11}$

1. Mixing of cryoprotective agent (Dimethyl sulfoxide, Ethylene glycol, Glycerol, Trehalose, Propylene glycol) with cells or tissues before cooling.

2. Specimen are cooled to low temperature and its storage.

3. Specimen is warmed.

4. Cryoprotective agents are remove from specimen after thawing.

\section{Thiel's Method of Embalming \& Its Modification}

Thiel's method of embalming is one of the famous and widely used method of preservation techniques with natural color comes in lime night in 1992 and so also 
called soft fix embalming method. The process involves the intravascular injection and the cadavers were submerged for a certain period of time in immersion solution., ${ }^{2,12}$ The use of conventional method leads body to become stiff and fragile, which leads to development of new method called Thiel's method, which is colorless, odourless due to very low concentration of formaldehyde, flexible, and mimic the feature close to fresh cadaver., ${ }^{2,13}$

The basic composition described by W Thiel in $1992 \mathrm{AD}$ for injection and immersion solutions are described in table 1 for body weight of $80 \mathrm{~kg}$. This process involves formation of two solution A and B. ${ }^{12}$ Now, the femoral or carotid artery is opened and intravascular solution containing solution A is perfused first followed by solution B, then sodium sulphite and formalin are added. After that cadavers are stored in the immersion solution for 6 months. ${ }^{12}$ The solution consists large amount of nitrite and sulphite salt with less amount of formaldehyde, ethylene glycol, boric acid and P-chloro $\mathrm{cresol}^{14}$, due to the formation of nitroso myoglobin the reaction between nitrites and myoglobin imparts intense red color stains to tissue, whereas ethylene glycol responsible for soft haptics of tissue whereas flexibility is developed due to boric acid which fragments the muscle protein in considerable amount. So, this method result into soft, flexible cadaver with natural color. ${ }^{15}$

Technique described by the thiel's was modified according to need by many embalmers such as Balta JY' $\mathrm{Y}^{13}$, Soames RW. ${ }^{16}$ The best embalming technique still consists some disadvantages as well, it has been reported that chemical used were poisonous, very flammable with explosive property, health hazardous with environment unfriendly and come under scrutiny in case of cost and histology. ${ }^{13,14,17}$

Table 1: Table showing composition of Thiel's embalming solution

\begin{tabular}{|c|c|}
\hline Solution A & Solution B \\
\hline 1. Boric acid (3 gm) & Ethylene glycol $(10 \mathrm{ml})$ \\
\hline 2. Ethylene glycol $(30 \mathrm{ml})$ & 4-chloro-3methyl phenol $(1 \mathrm{ml})$ \\
\hline 3. Ammonium nitrate (20 gm) & Immersion solution \\
\hline 4. Potassium nitrate $(5 \mathrm{gm})$ & 1. Ethylene glycol $(10 \mathrm{ml})$ \\
\hline 5. Hot water $(100 \mathrm{ml})$ & 2. Formaldehyde $(2 \mathrm{ml})$ \\
\hline Injection solution & 3. Solution B \\
\hline $\begin{array}{ll}\text { 1. } & \text { Solution A }(14300 \mathrm{ml})+\text { Solution } \\
\text { B }(500 \mathrm{ml}) \\
\text { 2. Formaldehyde }(300 \mathrm{ml}) \\
\text { 3. }\end{array}$ & $\begin{array}{ll}\text { 4. } & \text { Boric acid }(3 \mathrm{gm}) \\
\text { 5. } & \text { Ammonium nitrate }(3 \mathrm{gm}) \\
6 . & \text { Potassium nitrate }(10 \mathrm{gm}) \\
\text { 7. } & \text { Sodium sulfate }(7 \mathrm{gm}) \\
\text { 8. } & \text { Hot water }(100 \mathrm{ml})\end{array}$ \\
\hline
\end{tabular}

\section{Future of Embalming: Saturated Salt Solution}

called soft fix embalming method. The process involves the intravascular injection and the cadavers were submerged for a certain period of time in immersion solution. ${ }^{2,12}$ The use of conventional method leads body to become stiff and fragile, which leads to development of new method called Thiel's method, which is colorless, odourless due to very low concentration of formaldehyde, flexible, and mimic the feature close to fresh cadaver. ${ }^{2,13}$

The basic composition described by $\mathrm{W}$ Thiel in $1992 \mathrm{AD}$ for injection and immersion solutions are described in table 1 for body weight of $80 \mathrm{~kg}$. This process involves formation of two solution $\mathrm{A}$ and B. ${ }^{12}$ Now, the femoral or carotid artery is opened and intravascular solution containing solution $A$ is perfused first followed by solution $B$, then sodium sulphite and formalin are added. After that cadavers are stored in the immersion solution for 6 months. ${ }^{12}$ The solution consists large amount of nitrite and sulphite salt with less amount of formaldehyde, ethylene glycol, boric acid and P-chloro $\mathrm{cresol}^{14}$, due to the formation of nitroso myoglobin the reaction between nitrites and myoglobin imparts intense red color stains to tissue, whereas ethylene glycol responsible for soft haptics of 
tissue whereas flexibility is developed due to boric acid which fragments the muscle protein in considerable amount. So, this method result into soft, flexible cadaver with natural color. ${ }^{15}$

Technique described by the thiel's was modified according to need by many embalmers such as Balta $\mathrm{JY}^{13}$, Soames RW. ${ }^{16}$ The best embalming technique still consists some disadvantages as well, it has been reported that chemical used were poisonous, very flammable with explosive property, health hazardous with environment unfriendly and come under scrutiny in case of cost and histology. ${ }^{13,14,17}$

Bringing embalming techniques from Egyptian period to the 21st century, the future of embalming still resides on past anatomist Ambroise Pare (1510-1590), a pioneer in surgery who used common salt readily available in market as a component of embalming solution.15 To develop an ideal embalming solution with non-hazardous, relatively free from bacterial and fungal infection early in $1998 \mathrm{AD}$, Coleman and Kogan introduced a embalming fluid with very high salt and low $0.75 \%$ formaldehyde concentration embalming fluid and argued that high salt content retained in tissue prevents desiccation and cadavers were excellently preserved and color remain natural.13,15

In 21st century, medical schools, researchers, surgeons and anatomist required a development of internationally recognized standards on embalming technique that helps cadaver to be preserved in realistic manner and invites researcher to investigate. Similarly research performed by Gosomji IJ et al (2018), Nigeria on saturated solution on animal goat explained that saturated solution is best, affordable and accessible option, which not only maintains integrity of tissue but also maintains color shape and texture without distortion. 18

\section{CONCLUSION}

It is very interesting to make a keynote that modern embalming techniques are the result of accumulation of errors, trials and invention varied according to different cultures and people which was modified from time to time after discovery in the field of medicine. With the advancement of the technology, new embalming technique were developed and modified according to need with main objective of retarding the decomposition with excellent presentation. Therefore, embalming fluid which fix cellular protein and kills bacteria and fungus is actually a mixture of different chemicals which restores the body to acceptable physical appearance and can be researched according to need. We also would like to recommend that new internationally recognized standard on embalming technique should be developed so that cadavers were excellently preserved and color remains natural.so, that further research can be conducted without any health hazard.

\section{Acknowledgement}

We would like to thank to all who donated their body for the education and research purpose and this research would be incomplete without guidance of Prof Dr Chandra Bhushan Jha, Head, additional prof. Dr Shamsher shrestha and Dr Sarun Koirala, Department of Human Anatomy, B.P. Koirala Institute of Health Sciences, Nepal.

\section{REFERENCES}

1. Bradbury S, Hoshino K. An improved embalming procedure for long lasting preservation of the cadaver for anatomical study. Acta anat. 1978;101:97103. https://doi.org/10.1159/000144954 GoogleScholar | PubMed

2. Blessing A, Olubunmi E, Abidemi O. Human Embalming Techniques: A Review. AmJBiomedSci [Internet]. 2018;10(2):82-95. https://doi.org/10.5099/ aj180200082 Google Scholar | CrossRef

3. Bajracharya S, Magar A. Embalming: An art of preserving human body. KUMJ. 2006;4(16):554-7. Google Scholar | PubMed

4. Ezugworie J, Anibeze C, Ozoemena F, Ezugworie J, Anibeze C, Trends FO, et al. Trends in the development of embalming methods. Internet $\mathrm{J}$ Altern Med. 2008;7(2):1-6. https://doi.org/10.5580/29b Google Scholar | Full Text

5. Pal A, Batra S. Embalming and other methods of dead body preservation. Int J Med Toxicol Leg Med. 2010;12(3):15-9. Google Scholar | Full Text

6. Brenner E. Human body preservation-old and new techniques. J Anat [Internet]. 2014;224(3):316-44. https://doi.org/10.1111/joa.12160 GoogleScholar | CrossRef | PubMed 
7. Pandit S, Kumar S, Mishra BK. Comparative study of anatomical specimens using plastination by araldite HY103, polypropylene resin, 6170H19 Orthocryl and silicone -A qualitative study. Med $\mathrm{J}$ armed forces india. 2015;71(3):246-53. https://doi.org/10.1016/j. $\underline{\text { mjafi.2015.04.014 | GoogleScholar | CrossRef }}$

8. Pentea M, Hulea C, Stancu A, Butnariu M, Cristina RT. Developing the Plastination Laboratory for the Technique S10. Mater Plast. 2016;53(1):150-2. Google

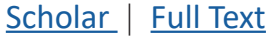

9. Elnady FA. The Elnady Technique : An Innovative, New Method for Tissue Preservation. ALTEX [Internet]. 2016;33(3):237-42.https://doi.org/10.14573/ altex.1511091 GoogleScholar | CrossRef

10. Bakhach J. The cryopreservation of composite tissues: Principles and recent advancement on cryopreservation of different type of tissues. Organogenesis [Internet]. 2009;5(3):119-26.https://doi.org/10.4161/org.5.3.9583 Google Scholar | CrossRef | PUBMED

11. Jang T, Park S, Yang J, Kim J, Seok J, Park U, et al. Cryopreservation and its clinical application. Integr Med Res [Internet]. 2017;6(1):12-8. https://doi. org/10.1016/j.imr.2016.12.001 CrossRef | PubMed

12. Ottone NE, Vargas CA, Fuentes R, Sol M del. Walter Thiel's Embalming Method. Review of Solutions and Applications in Different Fields of Biomedical Research. Int J Morphol. 2016;34(4):1442-54. https://doi.org/10.1016/j.imr.2016.12.001 GoogleScholar | Full Text

13. Balta JY, Twomey M, Moloney F, Duggan O, Murphy
$\mathrm{KP}$, Connor OJO, et al. A comparison of embalming fluids on the structures and properties of tissue in human cadavers. Anat Histol Embryol. 2019;48(1):6473.https://doi.org/10.1111/ahe.12412 Google Scholar | CrossRef

14. Hayashi S, Naito M, Kawata S, Qu N, Hatayama N, Hirai $S$, et al. History and future of human cadaver preservation for surgical training: from formalin to saturated salt solution method. Anat Sci Int [Internet]. 2016;91(1):1-7.https://doi.org/10.1007/s12565-0150299-5 Google Scholar | CrossRef

15. Hayashi S, Homma H, Naito M, Oda J. Saturated Salt Solution Method: A Useful Cadaver Embalming for Surgical Skills Training. Medicine (Baltimore) [Internet]. 2014;93(27):e196. https://doi.org/10.1097/ MD.0000000000000196 | GoogleScholar| CrossRef |

16. Eisma R, Lamb C, Soames R. From Formalin to Thiel Embalming: What Changes? One Anatomy Department 's Experiences. Clin Anat [Internet]. 2013;26:564-71. https://doi.org/10.1002/ca.22222 Google Scholar | CrossRef

17. Hammer N, Loffler S, Feja C, Sandrock M, Schmidt W, Bechmnn I, et al. Ethanol-Glycerin Fixation With Thymol Conservation: A Potential Alternative to Formaldehyde and Phenol Embalming. Anat Sci Ed [Internet]. 2012;5(4):225-33. https://doi.org/10.1002/ ase.1270 Google Scholar | CrossRef

18. Gosomji I, Omirinde J, Hena S, Wanmi N, Azeez I. Saturated salt solution an alternative reagent in reducing formaldehyde concentration in embalming. MOJ Anat Physiol. 2018;5(3):205-7. Google Scholar | Full Text 